\title{
Spatial Analysis of The Needs of Green Open Space at Universitas Negeri Padang
}

\author{
Muhammad Aliman ${ }^{a}$, Arisius Yustesia ${ }^{b}$, Eri Barlian ${ }^{c}$, Nurhasan Syah $^{d}$ \\ aTeacher of SMAN 15 Padang, Student Doctoral of Geography Education, Universitas Negeri Malang \\ ${ }^{b}$ Lecture of STKIP Kie Raha Ternate, Student Doctoral of Geography Education, Universitas Negeri Malang \\ ${ }^{\mathrm{c}}$ Lecture of Postgraduate, Universitas Negeri Padang \\ ${ }^{\mathrm{d}}$ Lecture of Postgraduate, Universitas Negeri Padang \\ Email: alviageo@gmail.com
}

\begin{abstract}
The decreasing of environmental quality in padang is caused by the changes of the land, the increasing number of vehicles and the increasing number of population. The solution to overcome these problems is by providing a green open space at universitas negeri padang (unp). The objectives of this study are 1) to analyze the needs of green open space at unp, 2) to plan the construction of open green space at unp. The method employed in this study was survey by using spatial analysis remote sensing data from google earth. The results of the study revealed that unp had open green space as large as 7.643 ha. The area of green open space at unp that fulfilled the width criteria was as much as $10 \%$, and the fulfillment of population and clean air criteria was as much as $20 \%$. However, the minimum width criterion of green open space, which was as much as $30 \%$, was not fulfilled yet. The discrepancy between the area of open green space and the criteria of minimum width $(30 \%)$ was 0.447 ha. Such lack of green open space can be filled by: optimizing the unoccupied land as large as 1.4 ha by planting the clump, providing 2308 flower's pots, and making use of building shelter and building lobbies, and campus corridor to be planted with clump, ornamental plants or other types of epiphytes and lianas.
\end{abstract}

Keywords: Green Open Space, Environment Quality, Spatial Analysis

\section{Introduction}

The quality of urban environments is declining for years, due to the decrease in green open space in urban areas because it is converted into shops, settlements, recreation areas, industries and others (Aliman, 2013; Sumarmi, 2010; Zain, Syarief, \& Hardjoamidjodjo, 2010). In addition, the factors causing the declining quality of urban environment due to the increasing number of people who need new settlement land, motor vehicles (Dinariana, 2011; Ritohardoyo, 2007). This is in accordance with the research (Endes Nurfilmarasa Dahlan, 2011) which mentions the growing number of people resulting in increased land demand while green open space decreases. Land use change in urban areas is a normal indication due to the developmental process of the city (Doxiadis, 1988). However, these changes need to be responded so that negative impacts can be minimized. Urban people have breathed dirty air from motor vehicle fumes (60-70\%) and factory smoke. (10-15\%) (Sulistijorini, 2009). The sources of pollutants come from industries, transportations, household and burning waste. The addition of infrastructure in the city to increase comfort and efficiency of society, such as transportation and various industrial products, also adds environmental burden such as the increase of air pollutant. 
Cities with many buildings will reflect back the sun in the form of long waves of far infrared rays so that the air temperature in the city is hotter than the temperature around the city (Endes Nurfilmarasa Dahlan, 2004). Major cities in Indonesia such as Jakarta, Surabaya, and even Padang show the air temperature is high enough (Sumarmi, 2010). This indication is known as Pulau Bahang (Heat Island) that has occurred in the city of Padang. The average daytime temperature reaches $34^{\circ} \mathrm{C}$ while at night the temperature is around $31^{\circ} \mathrm{C}$ (BMKG, 2017). The increasing temperature in urban areas globally, especially in Padang City is caused by several factors such as greenhouse gas effect, excessive carbon gas usage and fuel consumption from fossil (Astra, 2010; Supriatin \& Martono, 2016; Wallington, Srinivasan, Nielsen, \& Highwood, 2009). The increasing of temperatures can affect human comfort and productivity (Endes N. Dahlan, 2014).

According to (Permenhut RI No P.03/MENHUT-V/2004, n.d.), one alternative to overcome the problem is to increase the green open space (RTH). Reforestation of the city has not received adequate attention and is not balanced compared to physical development. According to (Endes Nurfilmarasa Dahlan, 2005) One way to reduce $\mathrm{CO}_{2}$ in urban areas is to build green open space. Green open space development must be well planned and integrated. Green open space is concerned with spatial and environmental plans to create a beautiful, clean, healthy and comfortable environment for urban communities. In addition, the trees in the middle of the city can reduce the surrounding temperature by $3.46 \%$ during the early days of the rainy season (Irwan, 1994). While the trees that make up the city forest can reduce the daily temperature by $30.2^{\circ} \mathrm{C}$ with air humidity of $74 \%$ (Endes N. Dahlan, 2014). In reality, however, there was a negative linear pattern of carbon presence in Padang City from 1988, 1998, and 2008. The decline in the amount of carbon stocks is caused by the decrease of forest area, shrubs, gardens or paddy cover and the increasing of settlement area (Hermon, 2012).

One of the public spaces in Padang City is the campus 1 of Universitas Negeri Padang (hereinafter referred to as UNP) located in North Padang Subdistrict. UNP Campus has the potential to become one of the open space in the city of Padang. Based on the data ('Overall Ranking 2016 | UI GreenMetric', n.d.) UNP is still at position 46 among the campuses in Indonesia. One indicator of the Green Metric UI assessment is the presence of green open space. The presence of the green open space UNP is an opportunity for UNP to improve its ranking in Indonesia. Some problems that arise in the campus environment is the lack of parking space, drainage is often clogged, the use of Air Conditioner (AC) in every room, the increase of pollutants due to the number of motor vehicles that pass through the campus. According to Agustin in (Sumarmi \& Amirudin, 2014) transportation emissions proved to be the highest contributor of air pollution in Indonesia, at $85 \%$.

According to (PP RI No 63 Tahun 2002, n.d.), the area of green space in a compact stretch is at least 0.25 (twenty five per one hundred) hectares. Furthermore, verse 3 states the percentage of green open space at least $10 \%$ of urban areas and / or adapted to local conditions. Green open space area of Padang City is 385 ha, while the area of built land is 7123,23 ha (Dinas TRTB, 2011). If the minimum green open space requirement is $10 \%$ of the land area, then Padang City must have green open space of 712,323 ha. From the difference, the city of Padang still lack of green open space of 327,323 ha. The deficiency when compared with the area of Padang City, the actual shortage of green space can be fulfilled from the forest area of Padang City as a whole that is 41,242.25 ha (Bapedalda, 2009). However, the location of the forest is far from the community activities in urban centers so it is not so influential on the microclimate in urban areas. Spatially, the distribution of urban forest in Padang is uneven. Therefore it is necessary to make efforts and planning to make urban forests in areas with solid activity.

Campus I UNP one of the fairly open land in the middle of the city can be utilized optimally to be green open space land. The green open space in question does not mean that UNP should provide a special area for the growth of forests, but from empty small areas and green building concepts can be utilized to 
present trees on campus. In knowing the ideal area of green space for the city of Padang, can be known through several approaches such as based on a large percentage of cities, based on PP. Republic of Indonesia No 63 of 2002, at least 0.25 (twenty five per cent) hectares and verse 3 says percentage of green open space at least $10 \%, 20 \%, 30 \%$ of urban areas and / or adapted to local conditions. Then based on the criteria of population, the calculation of the area of green open space based on the minimum value for each population is $1.5 \mathrm{~m} 2$ / townspeople (Endes Nurfilmarasa Dahlan, 2004). Based on the fulfillment of clean air, According to (Sitompul \& Marpaung, 2002) and modified with the opinion of Bernatzky (1978) in (Endes Nurfilmarasa Dahlan, 2004). This study aims to find out the need of green open space UNP area in accordance with the four above analysis and development plan. In the end, the ideal green space will be gained and will benefit UNP activities and even improve the quality of the environment in Padang City.

\section{Method}

Data taken in this research, is data derived from primary data and secondary data. Primary data include field observation and interview. Observations were made to see the real condition of existing trees and parks, and then interviews were conducted to obtain data on planning on the management of green open space. Secondary data collected were recent year's landsat imagery data obtained through Google Earth, UNP Map or master plan, UNP campus area, UNP population and a number of other supporting sources. Analysis of aerial photographs used ARCView GIS software version 10.1. The ideal width data of UNP's green open space is measured from a wide range of approaches such as percentage of $10 \%, 20 \%, 30 \%$, population, vehicle number, clean air fulfillment. Then the data was cross tabulated with spatial analysis result of RTH UNP availability.

\section{Results and Discussion}

UNP Campus is located in Kelurahan Air Tawar Barat Kecamatan Padang Utara Kota Padang. Astronomically the UNP is located at $0^{\circ} 53$ ' 49.16 "LS and $100^{\circ} 20^{\prime} 55.83$ " BT. UNP campus has alluvial precipitation because its position is less than $1 \mathrm{~km}$ from the coast. UNP Campus in Air Tawar before 1966 is a land of citizens who gradually purchased by the campus. Land area of 26.9 ha was purchased in 27 plots along with the land certificate. In this study, some areas are divided into certain clusters, the details can be seen in the following table:

Table 1. UNP Cluster Location Name

\begin{tabular}{|c|l|l|}
\hline No & Nama Klaster & \multicolumn{1}{|c|}{ Lokasi } \\
\hline 1 & Kuning & Rectorate, Field, UNP Gate \\
\hline 2 & Hijau & faculty of Science Education \\
\hline 3 & Merah & Faculty of Social Science \\
\hline 4 & Merah Jambu & Faculty of Economics, PKM, \\
\hline 5 & Orange & Faculty of Engineering \\
\hline 6 & Ungu & Faculty of Languages and Letters \\
\hline 7 & Putih & Postgraduate \\
\hline 8 & Biru & Faculty of Mathematics and Natural Sciences, Central Library \\
\hline 9 & Hijau Muda & faculty of Sport Science \\
\hline 10 & Coklat & LPMP \\
\hline 11 & Abu-abu & Komplek Sekolah Labor \\
\hline 12 & Biru Muda & Al-Azhar Mosque, Tutorial Center \\
\hline
\end{tabular}

Source: Spatial Anayisis (2016) 
The name of the cluster is based on the UNP statute, ie each faculty has a specified color. While the name Klaster LPMP, school complex laboratory and tutorial center is a naming by researchers. This cluster division is expected to make it easier for planners to build or revitalize trees and parks that already exist. This relates to the scope and responsibility of its maintenance, the responsibilities imposed on faculty, work units or directly under the university.

The silvicultural technique aspect for green open space UNP is: derived from healthy selective seed and disease-free, has perfect growth of both stem and root, comparison of shoots and roots balanced, stems erect and hard at the base, symmetrical and solid header, solid root system. The biological properties of green open space UNP are: Grows well on solid soil, root system enters the soil, not to damage the construction and building, the phase of the seedlings grow fast, grow slowly in the adult phase, the size of adult according to available space, branch and branching system are strong, strong erect stem, not easily broken and unbushed, the stature and shape of the canopy is quite beautiful, the canopy is quite shady and compact, but not too dark, the size and shape of the canopy is balanced by the height of the tree, The leaves should be narrow (nano fill) does not shed leaves, the leaves do not easily fall out because of strong winds, when the flowering / fruiting does not contaminate the road, small fruit and can not be eaten by humans directly, should not be prickly or poisonous, easily recover if get injury caused by impact / incision, resistant to pests, resistant to motor vehicle pollution and industry, able to absorb and absorb air contamination, as far as possible have economic value, long life.

The UNP landscape landscape planning is a consideration of the aesthetic side and its benefits. The green open landscape is 1) shade tree, placed on the plant path (at least $1.5 \mathrm{~m}$ from the median edge), $2 \mathrm{~m}$ branching on the ground, the branching shape of the stems do not duck, the solid leaf mass, derived from seed propagation, Lined up, not easily uprooted. 2) Absorbent of air pollution: consists of trees, shrubs / shrubs, has a usefulness to absorb air, spacing tightly, mass of solid leaves. Landscape noise damper: consists of trees, shrubs / shrubs, forming mass, mass of dense leaves, various forms of crowns. Wind-breaking lobes: tall plants, shrubs / shrubs, solid leaf mass, planted in a march or form a mass, spaced tightly $<3 \mathrm{~m}$. Landscaping landscape: tall plants, shrubs / shrubs, mass of solid leaves, planted in a march or form a mass, spaced tightly.

The landscape arrangement at the intersection is a hallmark of the intersection or local location. Placement and selection of ornamental plants and ornaments should be adjusted to the geometric requirements of the road junction and must meet the following criteria: the free area is not allowed to be planted with plants that obstruct the view of the driver. Should use low plants shrub-shaped plants with a height of $<0.80 \mathrm{~m}$, and the type is flowering or beautiful structure. When at the intersection there are islands of traffic or canals that are possible to be planted, Should be used for low shrub plants with the consideration that not to interfere with pedestrians and do not block the view of the driver of the vehicle.

From the shape and structure of the green space, then modified by the researchers into several items, among others: clustered many strata, clustered two strata, strata two, strata spread many, and spread strata two. The modifications are made based on aesthetic and safety considerations. For more details of green open space planning at UNP, can be seen from the map planning below. Institutionally, the designation of green open space in UNP is still not supported by adequate regulations. UNP's strategic plan for 2007 - 2011 is contained in goal 3, namely governance, accountability and public imaging. At point $b$ mentioned that UNP target one of the development of facial and physical condition of campus beautiful, fresh, comfortable, and safe.

In order for urban development planning to achieve results those are able to maintain the function of a sustainable urban environment. In the principle of "good environmental governance", it takes at least three basic capital of development, namely: the availability of a reliable campus manager, in the form of human 
resources (HR) both campus officials and students who are able to jointly maintain the function and condition of the campus environment, according to the rules of preservation of existing environmental functions; the availability of ongoing financial resources support to support RTH maintenance and monitoring activities; the availability of comprehensive and dynamic RTH master plan in development development.

In building green open space, facilities and infrastructure are needed, both in post-plant and post-planting facilities. Based on the results of interviews conducted, the facilities used by janitors are still on the responsibility of each faculty. The provision of facilities and infrastructure has not been well integrated. The UNP Planning UNP is made into the planning map. The map informs the location of UNP clusters on the design of green open space shapes and structures. This paper gave birth to an idea with the term Rangkiang which is already very famous especially in West Sumatra. Rangkiang is an acronym of Design, Campus, Beautiful, Safe, Comfortable, Green.

Broad calculation of RTH UNP, spatial analysis used software Arc View GIS 10.1. that resulted in a UNP vegetation map. From the map it is found that UNP now has an green open space of 7,643 ha. The number of green space supports research (Septriana, 2005) which states that the constraints of urban forest presence in Padang City are still not spatially distributed. This forest area is the result of generalizing trees, gardens, shrubs and grasses. The availability of green open space will be compared with the calculation of green space needs based on five criteria. Based on the above table, it can be seen that from the five criteria which become the calculation of the area of green open space, there are four criteria that meet the needs of the area of green space. Criteria that have not met the criteria is $30 \%$ with the amount of deficiency that is an area of $0.447 \mathrm{ha}$. The unfulfilled criteria are normal. The 30\% of Government Regulation No 32 of 2002 is very big and maximum from the total area of UNP fresh water campus which only 26,956 ha. The shortage can be overcome by utilizing an empty land area of 1.4 ha that can be planted with shrubs. This area is not a special area, but is a small area between buildings, roadsides and vacant land that is only filled with grass and shrubs and spread unevenly in UNP.

Apart from the utilization of vacant land, potential green space that can be developed is the use of potted plants in each study room. If calculated the amount of study space available in UNP, including school labor, it is assumed that each room can provide four pots. Each potted plant measuring $30 \mathrm{~cm} \mathrm{x} 30 \mathrm{~cm}$ or an area of $90 \mathrm{~cm} 2$. From the 4 pieces of the pot, the number of rooms on the campus UNP estimated 577 units, that number does not include WC, mushola, and mosque. So the total potted plants that must be provided as much as 2308 pieces. From the results of these calculations, obtained the potential area to increase the green open space UNP, which is an area of 2.08 ha. In addition to pot plant potentials, another potential that can be developed is the manufacture of green floors and green poles is to plan the manufacture of creeping plants in the lobby of the building or on the corridor path.

\section{Conclusion}

Based on the objectives and research results, it can be concluded, among others: Planning and development of RTH UNP can be done, considering four of the five criteria of RTH needs are met. There is no specific planning that studies the RTH UNP, but in general has become a campus program. Campus is an academic container that needs to be created as secusively as possible to support a comfortable lecture environment and avoid urban environmental problems. The solution given for the lack of RTH based on $30 \%$ criteria is by optimizing vacant land around the campus building and the addition of flowerpot plants. Based on the conclusions, the implication is the leadership and academic community of UNP must implement planning and development of green open space in UNP along with physical development of campus. Physical development should be followed by the planned green open space development. It aims to be an integrated and sustainable development. Establish and provide broad institutional policies and spaces such as the UNP 
Study Center for the Environment (PSLH) to plan and develop the green open space. The flexibility of the executor will be beneficial to the smoothness of program activities that have been made. With green open space planning and development, green open space arrangement in UNP will be more organized and in accordance with the rules of the existing theory. In addition, with the UNP green open space planning, the use of vacant land, shelter building and utilization of corridor piles for creeping plants can be optimized. Based on the research findings, it is suggested that the following things are: UNP rector should plan specifically the campus greening program. The green open space planning should be used as a written regulation with a standard and sustainable institutional system. All of part of UNP such lecturers, students and employees must support the planning and development of UNP green open space in various forms and actions. This can be done by keeping the plants from damage, maximizing the performance of janitors. Fulfilling the shortage of green open space can be done by utilizing vacant land around the building, utilizing shelter of building, lobby of building, and campus corridor to be planted with shrubs, ornamental plants or epiphytes and lianas.

\section{References}

Aliman, M. (2013). Perencanaan dan Pengembangan Ruang Terbuka Hijau Universitas Negeri Padang (Thesis). Pascasarjana Universitas Negeri Padang, Padang.

Astra, I. M. (2010). Energi dan dampaknya terhadap lingkungan. Jurnal Meteorologi Dan Geofisika, 11(2). Retrieved from http://202.90.199.54/jmg/index.php/JMG/article/view/72

Bapedalda. (2009). Ruang Terbuka Hijau Kota Padang.

BMKG. (2017). Prakiraan Cuaca. Retrieved from file://C:/Users/ASUS\%20x200/AppData/Roaming /Mozilla/Firefox/Profiles/8yacnama.default/zotero/storage/PE7K4HGE/www.bmkg.go.id.html

Dahlan, E. N. (2004). Membangun Kota Kebun (Garden City) Bernuansa Hutan Kota. Bogor: IPB Press.

Dahlan, E. N. (2005). Hutan Kota untuk Pengelolaan dan Peningkatan Kualitas Hidup. Retrieved 22 September 2016, from

Dahlan, E. N. (2011). Kebutuhan Luasan Hutan Kota sebagai Rosot (sink) Gas C02 untuk mengantisipasi Penurunan Luasan Ruangan Terbuka Hijau di Kota Bogor. Journal Forum Geografi, 25(2), 164-177.

Dahlan, E. N. (2014). Karakter Fisik Pohon Dan Pengaruhnya Terhadapiklim Mikro (Studi Kasus di Hutan Kota dan RTH Kota Semarang). Jurnal Forum Geografi, 28(No 1), 83-90. https://doi.org/10.23917/forgeo.v28i1.440

Dinariana, D. (2011). Model Pengelolaan Ruang Terbuka Hijau sebagai Daerah Resapan di Wilayah DKI Jakarta (Disertasi). Institut Pertanian Bogor, Bogor.

Dinas TRTB. (2011). Penggunaan Lahan di Kota Padang.

Doxiadis, C. (1988). An Introduction to the Science of Human Settlements. London: Hutchinson \& Co Ltd.

Hermon, D. (2012). Dinamika Cadangan Karbon Akibat Perubahan Tutupan Lahan Permukiman di Kota Padang Sumatera Barat. In Forum Geografi: Indonesian Juornal of Spatial and Regional Analysis (Vol. 26, pp. 45-52). Uniiversitas Muhammadiyah Surakarta. Retrieved from http://repository.unp.ac.id/1186/

Irwan, Z. D. (1994). Peranan Bentuk dan Struktur Hutan Kota Terhadap Kualitas Lingkungan Kota (Studi Kasus Lokasi Permukiman Kota Jakarta). Institut Pertanian Bogor, Bogor.

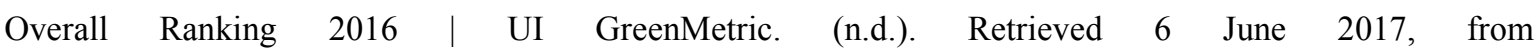
http://greenmetric.ui.ac.id/overall-ranking-2016/

Permenhut RI No P.03/MENHUT-V/2004. Pedoman Pembuatan Tanaman Penghijauan Kota, Gerakan Nasional Rehabilitasi Hutan dan Lahan (GNRHL).

PP RI No 63 Tahun 2002. Hutan Kota. 
Ritohardoyo, S. (2007). Perubahan Permukiman Perdesaan Pesisir Kabupaten Gunung kiDul Daerah $\begin{array}{lllll}\text { Istimewa } & \text { Yogyakarta } & \text { Tahun } & \text { 1996-2003. } & \text { Retrieved }\end{array}$ https://publikasiilmiah.ums.ac.id/handle/11617/271

Septriana, D. (2005). Perencanaan Pengembangan Hutan Kota di Kota Padang Sumatera Barat (Thesis). Institut Pertanian Bogor, Bogor.

Sitompul, L., \& Marpaung, B. (2002). Format ideal Hutan Kota di Kota Medan Berdasarkan Pendekatan Daerah Aliran Sungai. Presented at the Seminar Sehari Format Hutan Kota dan Hutan di Sepanjang Daerah Aliran Sungai untuk Menanggulangi Banjir, Paru-paru Kota dan Prospek Wisata Sungai Masa Depan, Medan. Retrieved from http:/USU digital library.com

Sulistijorini. (2009). Keefektifan dan Toleransi Jenis Tanaman Jalur Hijau Jalan dalam Mereduksi Pencemar NO2 akibat Aktivitas Transportasi (Disertasi). Institut Pertanian Bogor, Bogor.

Sumarmi. (2010). Upaya Peningkatan Partisipasi Masyarakat dalam Pengelolaan Ruang Terbuka Hijau (RTH). Pidato Guru Besar dalam Bidang Geografi Lingkungan. Universitas Negeri Malang. Universitas Negeri Malang. Retrieved from http://www.um.ac.id//page/guru-besar-fis

Sumarmi, \& Amirudin, A. (2014). Pengelolaan Lingkungan Berbasis Kearifan Lokal. Malang: Aditya Media Publishing.

Supriatin, L. S., \& Martono, M. (2016). Impacts of Climate Change (El Nino, La Nina, and Sea Level) on the Coastal Area of Cilacap Regency. In Forum Geografi (Vol. 30, pp. 106-111). Retrieved from http://journals.ums.ac.id/index.php/fg/article/view/2449

Wallington, T. J., Srinivasan, J., Nielsen, O. J., \& Highwood, E. J. (2009). Greenhouse gases and global warming. ENVIRONMENTAL AND ECOLOGICAL CHEMISTRY-Volume I, 6, 36.

Zain, A. F., Syarief, A., \& Hardjoamidjodjo, S. (2010). Deteksi penurunan ruang terbuka hijau dan dampaknya terhadap peningkatan kawasan rawan banjir di Kota Padang. Retrieved from http://repository.ipb.ac.id/handle/123456789/66907 